\title{
FACTORS INFLUENCING THE ADOPTION OF IMPROVED VEGETABLE PRODUCTION PRACTICES AMONG WOMEN FARMERS IN AGUATA- AGRICULTURAL ZONE, ANAMBRA STATE, NIGERIA
}

\author{
*Odoemlam L.E and Nzeakor, F.C \\ Department of Rural Sociology and Extension \\ Michael Okpara University of Agriculture Umudike, Abia State, Nigeria \\ Email: lovinasteve@gmail.com
}

\begin{abstract}
The study examined the level and determinants of adoption of improved vegetable production practices in the study area. A three-stage sampling procedure was used in the selection of 160 respondents. A structured questionnaire was used for data collection. Data collected were analysed using descriptive statistics and Probit regression model. Results on adoption level of the selected improved vegetable production practices indicated that improved seeds had a grand mean of $\bar{x}=$ 3.17, field preparation $(\bar{x}=3.19)$, planting distance $(\bar{x}=2.99)$, water management $(\bar{x}=3.43)$, fertilizer/organic manure application $(\bar{x}=3.55)$, pesticides $(\bar{x}=2.57)$, harvesting $(\bar{x}=5.00)$ and storage procedure $(\bar{x}=4.89)$ based on 5-point Likert scale adoption level. On factors influencing adoption of improved vegetable production practices, the result revealed that farm size $\left(1.00188^{\star * *}\right)$, credit access $\left(4.704902^{\star *}\right)$, on-farm demonstration $\left(2.900749^{* *}\right)$ and farm labour $\left(1.295902^{* * *}\right)$ had a positive and significant influence on improved vegetable production practices by the respondents. The result further indicated that the age $\left(0.3135258^{* *}\right)$ and the off-farm income $(0.0870768)$ of the farmers had a negative influence on the adoption of improved vegetable production practices. Based on these findings, the study revealed that the women farmers could have full adoption of the improved production practices if the factors are adequately addressed. The study therefore recommends that before the introduction of a new technology, the ADPs should ensure that maximum audience analysis is carried out to address some of the factors influencing adoption. Besides, introduction of new technologies to farmers should go hand-in-hand with onfarm demonstration since it is by that they would develop confidence and allay their fears associated with improved practices.
\end{abstract}

Keywords: Fadama, women farmers and improved vegetable production practices 


\section{INTRODUCTION}

Vegetable is defined as an edible plant or portion of an herbaceous annual or perennial crop which could either be served raw (green/fresh) or after a little cooking. Vegetable production is one of the global activities practiced in every economy, since it forms a major component of human diet. Studies discovered that not only is the global vegetable production increased by $100 \%$ in recent time, but also its trade value has exceeded that of cereals.

The Agricultural Development Projects (ADPs) was first launched as a viable project in 1972. The project was launched against the background of the Nigerian agriculture which has attained prominent expertise through complete reliance on small scale farmers. Their benefits were realized through a re-organized and revitalized agricultural extension system that integrates extension workers training and farm visits and ensure two-way communication between farmers and researches, an effective farm inputs distribution system which operates through a network of farmer service centres ensuring that supplying the needed farm inputs are reliable and in close proximity to their farms.

The goal of the government in establishing the ADPs is to achieve self-sufficiency in food and fishery production for both human and industrial consumption. Oyedoyin et al., (2013) claimed that the process of technology development, transfer and use is dynamic. As a result, issues concerning to this must reflect the change in institutions through sustained use of agricultural technologies.

The progress made in agricultural production achieved so far through the enclave Agricultural Development Projects (ADPs) compared with the situation before the adoption of ADP approach encouraged the Nigerian government to establish the ADPs on a nationwide basis in all the states of the federation with the focus on small scale farmers (Nwalieji and Ajayi, 2009).

Small holder agriculture, the main occupation of rural communities in Nigeria, is mainly rain fed and characterized by low land and labour productivity. Yet, Nigeria as a country has a very good comparative advantage in the production of a variety of fresh and high processed value crops especially during the dry season. This is because the country is blessed with underground and surface water reserves, rich in pastures and favourable agro-ecological conditions in the country's low-lying plans with alluvial deposits called fadama. In the light of these potentials, the first National Fadama Development Project (Fadama I) was designed in the early 1990s to promote simple and low-cost improved irrigation technology under World Bank financing.

A survey was carried out in Anambra State to determine both surface and underground water sources in the State as part of its programmes to increase dry season vegetable production and other farming activities in the State. The study showed that small-scale Fadama (irrigation) was feasible in Anambra state, using simple low-cost technologies to harness the surface and shallow 
underground water resources (Nwadukwe, 2000). About 30,000 hectares of land in the state was then identified as having the capacity to support the Fadama 1 project.

Irrigation is defined as the supplement of precipitation by storage and transportation of water to the field for growth of agricultural crops. Irrigation farming is a means to reduce risks in farming, ensure high yields as well as make production possible throughout the year. It is often the recommended strategy to reduce risk associated with rainfall variables and increase yields of food crops, Matata et, al (2010).

Anambra state is one of the most climatic states in South-east, Nigeria. Improved farm practices are therefore needed to become more available to improve the livelihoods of farmers. Several practices and technologies are available for small holders' farmers to enable them better adapt to the effect of climate change. So, linking farmers to new sources of information on technologies will be important, but it is equally important in deciding the potential factors of technology adoption at farm level that influence their decisions.

Several factors may influence the extent of adoption of farm practice such as characteristics of farm practice, the adopters, the change agents and the socio-economic biological and physical environment in which the technology takes place. Socio-psychological trait of farmers also plays an important role in technology adoption. The age, educational level, income, family size, tenure status, credit use, value system, and beliefs are usually positively related to adoption. From the existing literatures, it is evident that adoption of technologies in farming practices is affected by certain factors Adebiyi and Okuntola (2013). The farmer's attitude towards change, organization, land, source of information, membership of farm, educational level, farm income, farmer's exposure, are the important socio-economic factors influencing adoption of farm innovations (Agu, 2002). Researches has reported that adoption of new technologies is more pronounced among young and educated individual farmers, and also positively influenced by higher income level, risk orientation and decision-making ability of farmers. In contrast, adoption of technology is limited among conservative old people, and illiteracy, weak belief on yield of new technology, among others. These suggest that the use of technologies by farmers is influenced by various socioeconomic factors.

This National Fadama Development Project (NFDP) (Phase I) was designed in early nineties and introduced to rural farmers to promote simple and low-cost improved irrigation technologies under World Bank. NFDP (Phase I) covered many areas of agricultural production including vegetable production. The study is limited to vegetable production only. The NFDP (Phase 1), which implementation lasted for a period of six years came to an end in December 2002. Within this period of years, the NFDP was expected to have achieved its pre-determined objectives especially 
with respect to improved vegetable production all through the year. Upon all those huge expectations, the level of involvement of farmers in the use of improved vegetable production practices and availability of these vegetables all year round is not clearly visible; because they are still scarce and expensive.

The Fadama Development Project (Phase I) was introduced in Anambra State ADP (ASADEP) in 1996 as part of its development objective to increase the incomes of users, reduce rural poverty, increase food security and contribute to the achievement of a key Millennium Development Goal (MDG). Dry vegetable production was introduced as one of the components of Fadama Programme, to help solve the problem of scarcity of vegetables during off-season because of selfreliance on rainfed agriculture.

Based on this premise; the main objective of this study is to determine factors influencing the adoption of improved vegetable production practices in Anambra State. The specific objectives are to

1. describe the socio-economic characteristics of the farmers,

2. determine the level of adoption of improved vegetable production practices by the farmers, and

3. determine factors that influence the adoption of improved vegetable production practices in the study area.

\section{METHODOLOGY}

The study was conducted in Aguta Agricultural Zone of Anambra State, Nigeria. The area lies between latitude of $6013^{1}$ and $709^{1} \mathrm{~N}$ of the equator and longitudes $7049^{1}$ and $7057^{1} \mathrm{E}$ of Greenwich Meridian. Aguta Agricultural zone is sandwiched between Akokwa in Orlu South Local Government Area (LGA) of Imo State, in the south, Awlaw in Oji River LGA of Enugu State in the east and on the west by Umuaka in Umunneochi LGA of Abia State.The zone is made up six blocks, namely Aguta I and Aguta II, Orumba I and Orumba II, Orumba III and Nnewi.

Three-stage random sampling technique was used in the selection of respondents for the study. First, three of the six blocks were randomly selected. The selected blocks were Aguta II, Orumba 1 and Nnewi. Second, two circles were selected randomly. The selected circles were Umuchu and Akpo in Aguta II, Ogboji and Uga in Orumba II and Ukpor and Achima in Nnewi. Those communities and villages selected were those that had the capacity to support FADAMA development. In the third stage, 20 women farmers were selected from each circle, giving a total of 160 respondents. 


\section{Data Collection and Analysis}

Data were collected with the use of interview and analyzed with frequency distribution, means and Probit regression model.

Descriptive statistics was used to analyze the socio-economic characteristics of the respondents.To determine the level of adoption adoption of improved practices by the farmers, respondents were asked to identify their adoption status on a 5-point Likert scale. Their responses were rated as: Aware $(A w)=1$; Interest $(I N)=2$; Evaluation $(E V)=3$; Trial $(T R)=4$; Adoption $(A D)$ $=5$. The adoption mean $(\bar{x})$ score per innovation was computed by dividing the total adoption scores by the number of respondents involved, and the grand mean $(\bar{x})$ adoption score was calculated by adding all the mean adoption score and then divide by the number of the innovation considered. Thus, three (3.0) was used as the benchmark for the assessment.

1. The total adoption score per each practice was calculated.

2. To determine the factors influencing the adoption of improved vegetable production by the farmers, the Probit regression model was used. It is specified in the implicit form as follows:

$Y=a+b_{1} x_{1}+b_{2} x_{2}+b_{3} x_{3}--------+b n\left(x_{n}\right)+e$

Where;

$Y=\quad$ adoption level (dummy variable, adopted 1; otherwise 0 )

$a=$ constant

$X_{1}=\quad$ Farmers' age (years)

$X_{2}=\quad$ Educational level (years of formal learning)

$X_{3}=$ Farm size (hectares)

$X_{4}=$ On farm demonstration (Participated 1; None 0 )

$X_{5}=$ Off farm income (in naira)

$X_{6}=$ Family labour (Man hour)

$X_{7}=$ Access to credit; (Access 1; non-access 0 )

$X_{8}=$ Compatibility of the technology - this was measured using a 5-point scale

$\beta_{1}=$ Regression coefficient

e $=$ error term 


\section{RESULTS AND DISCUSSION}

\section{Socio-economic characteristics of the Farmers}

The result in Table 1 shows that the majority of the respondents (33.8\%) were between the age of $40-45$ years of age, meaning that they are still active in productive and reproductive life. The implication is that at this age, they are likely to be more responsive to vegetable production improvement programme in the study area. Older adults as a group tend to be slower than younger adults to adopt new technology (Ironkwe et al., 2016). Age is assumed to be a serious factor in of adoption of new innovation. Older farmers are assumed to have gained knowledge and experience over time and are better able to evaluate technology information than younger farmers (Mwangi and Kariuki, 2015). Understanding these individuals and age-related differences provide guidance for the introduction of new technologies that may be of benefit to users. The results further revealed that majority of the respondents were literate. High level of literacy among the respondents may facilitate better adoption of the improved vegetable production practices of ability to teach others effectively. This result is in support of the findings of Agwu and Anyaeche (2007) which revealed that adoption of innovation is enhanced by high rate of literacy and formal education, as literate farmers can understand the innovation effects of the extension agents and their implication better than illiterate farmers. The level of education influences the kind of opportunities available to improve livelihood strategies, enhanced food security, and reduction in the level of poverty Etuk et, al, (2018).

The results further show that most (58\%) of the farmers were married, $36 \%$ were single while $44 \%$ were widowed. Married farmers may have large household sizes, which may encourage them to adopt many improved practices in order to raise their income and living standard of their households (Kariyasa and Dewi, 2011).

Table 1 shows that most of the respondents had a household size of between 14 and 16 people. Household size is simply used as a measure of labour availability and also enhances farm labour participation. Large households are expected to encourage adoption of innovation as it relaxes the labour constraint required during the introduction of new practices. The implication of this findings is that more family labour for vegetable production would be readily available since relatively large household size is an obvious advantage in terms of labour supply. 
Table 1: Socio-Economic Characteristics of the Respondents

\begin{tabular}{|c|c|c|}
\hline Variables & Frequency & Percentage (\%) \\
\hline \multicolumn{3}{|l|}{ Age: } \\
\hline $30-35$ & 30 & 18.8 \\
\hline $40-45$ & 54 & 33.8 \\
\hline $50-55$ & 43 & 26.9 \\
\hline $60-65$ & 24 & 15.0 \\
\hline $70-75$ & 9 & 5.5 \\
\hline Mean & 40.00 & \\
\hline \multicolumn{3}{|l|}{ Educational Level: } \\
\hline Non-formal & 64 & 40 \\
\hline Primary education & 38 & 23.8 \\
\hline Secondary & 51 & 31.9 \\
\hline Tertiary & 7 & 4.3 \\
\hline \multicolumn{3}{|l|}{ Marital status: } \\
\hline Married & 92 & 57.5 \\
\hline Single & 58 & 36.2 \\
\hline Widow & 10 & 6.3 \\
\hline \multicolumn{3}{|l|}{ Household size: } \\
\hline $2-4$ & 18 & 11.0 \\
\hline $5-9$ & 32 & 20.0 \\
\hline $10-12$ & 49 & 31.0 \\
\hline $13-16$ & 61 & 38.0 \\
\hline Mean & 7 & \\
\hline \multicolumn{3}{|l|}{ Access to credit } \\
\hline Yes & 31 & 19.4 \\
\hline No & 129 & 80.6 \\
\hline \multicolumn{3}{|c|}{ Farming experience (years) } \\
\hline $1-10$ & 28 & 17.5 \\
\hline $11-21$ & 54 & 33.8 \\
\hline $21-30$ & 56 & 35.0 \\
\hline $31-40$ & 22 & 13.7 \\
\hline Mean & 16.7 & \\
\hline \multicolumn{3}{|c|}{ Farm size (hectares) } \\
\hline $0.5-1.0$ & 103 & 64.4 \\
\hline $1.1-1.5$ & 43 & 26.9 \\
\hline $1.6-2.0$ & 15 & 9.4 \\
\hline Mean & 0.85 & \\
\hline
\end{tabular}


Findings indicated that $80.6 \%$ of the respondents did not have access to credit while $19.4 \%$ did. Credit is a very strong important factor that is needed to acquire or develop farm enterprise. Its availability could determine the extent of production capacity.

Experience is gained with age, considering the major occupation of the respondents which is farming, the length of time in farming can be linked with the age of the farmers. Results revealed that $35.0 \%$ of the respondents had been in farming for $21-30$ years. With these farming experience of the respondents, it is expected that the respondents will be able to make a sound decision as regards resource allocation and management of the farm. Experience gained by farmers in agricultural production activities helps them to bear the risk and uncertainties associated with farming, Nwaobiala et, al (2019).

The size of the farm cultivated is a function of population pressure, family size and financial background of the farmers. One major characteristics of the farmers was fragmented land holdings. Results in Table 1 show that $64.4 \%$ had $0.5-1.0$ hectares of land, 26.9\% (1.1 - 1.5 hectares of land) and $9.4 \%$ (1.6 -2.0 hectares of land). It then implies that all the respondents were small scale farmers.

\section{Adoption of Improved Practices by the Farmers}

Table 2 shows the level of adoption of improved vegetable production practices by the women in the study area. The mean adoption levels of improved practices for the production of Telfaria, Okra, and Amaranthus were 3.4, 3.47 and 3.36 respectively. The implication of the results is that Telfaria, okra, Amaranthus production practices were still at the evaluation stage. This implies that the farmers were still practicing the old methods and at the same time comparing the usefulness of the new improved practices over their old local methods. The mean adoption rate for tomato was 2.11. This indicates that tomato practices were still at the trial stage. The grand mean for improved vegetable seed $(\bar{x}=3.54)$ indicating evaluation stage in the adoption level. 
Table 2: Adoption Level of Selected Improved Vegetable Production Practices

\begin{tabular}{|c|c|c|c|c|c|c|c|}
\hline \multirow[t]{2}{*}{ Improved vegetable production technologies } & \multicolumn{5}{|c|}{ Adoption level } & \multirow{2}{*}{$\begin{array}{l}\text { Total } \\
\text { adoption } \\
\text { score }\end{array}$} & \multirow{2}{*}{$\begin{array}{l}\text { Means } \\
\text { (x) }\end{array}$} \\
\hline & $\begin{array}{l}\text { AW } \\
(1)\end{array}$ & $\begin{array}{l}\text { Int } \\
(2)\end{array}$ & $\begin{array}{l}\text { Eva } \\
\text { (3) }\end{array}$ & $\begin{array}{l}\mathrm{TR} \\
(4) \\
\end{array}$ & $\begin{array}{l}\text { Adopt } \\
(5)\end{array}$ & & \\
\hline \multicolumn{8}{|l|}{ (A.) Improved seeds } \\
\hline Telfaria & 15 & 38 & 31 & 15 & 61 & 549 & 3.43 \\
\hline Okra & 12 & 18 & 54 & 28 & 48 & 562 & 3.75 \\
\hline Amaranthus & 4 & 34 & 51 & 42 & 29 & 538 & 3.36 \\
\hline Tomatoes & 62 & 38 & 27 & 18 & 15 & 326 & 2.11 \\
\hline \multicolumn{8}{|l|}{$\begin{array}{l}\text { Grand mean }(x=3.17) \\
\text { (B.) Field preparation }\end{array}$} \\
\hline Check basin & 18 & 29 & 51 & 32 & 20 & 475 & 2.96 \\
\hline Sunken bed & 21 & 14 & 62 & 18 & 48 & 547 & 347 \\
\hline \multicolumn{8}{|l|}{$\begin{array}{l}\text { Grand mean }(x=3.19) \\
\text { (C.) Planting distance }\end{array}$} \\
\hline Telfaria $(50 x 50)$ & 48 & 24 & 36 & 20 & 32 & 4.14 & 2.78 \\
\hline Okra $(60 \times 60 \mathrm{~cm})$ & 52 & 12 & 41 & 36 & 19 & 4.38 & 2.70 \\
\hline Amaranthus $(50 \times 30 \mathrm{~cm})$ & 28 & 34 & 37 & 25 & 36 & 487 & 3.04 \\
\hline Tomatoes $(50 \times 30 \mathrm{~cm})$ & 31 & 52 & 24 & 31 & 42 & 541 & 338 \\
\hline \multicolumn{8}{|l|}{ Grand mean $(x=2.99)$} \\
\hline \multicolumn{8}{|l|}{ (D.) Water management } \\
\hline Use of water pump & 42 & 16 & 21 & 37 & 44 & 5.05 & 3.16 \\
\hline Use of tube - well/wash bore & 16 & 18 & 28 & 35 & 63 & - & 3.69 \\
\hline Stacking (esp. Telfaria) & 25 & 35 & 41 & 16 & 43 & 497 & 3.11 \\
\hline \multicolumn{8}{|l|}{ Grand mean $(x=3.43)$} \\
\hline Organic fertilizer (Compost) & - & - & - & 73 & 87 & 727 & 4.50 \\
\hline In organic fertilizer (N.P.K) & 19 & 25 & 38 & 41 & 37 & 532 & 3.33 \\
\hline \multirow{2}{*}{\multicolumn{8}{|c|}{$\begin{array}{l}\text { Grand mean }(x=3.55) \\
\text { (F.) Pesticides }\end{array}$}} \\
\hline & & & & & & & \\
\hline Use herbicide: round up & 35 & 57 & 36 & 28 & 10 & 407 & 2.54 \\
\hline Insecticides : Karate & 33 & 29 & 28 & 25 & 40 & 333 & 2.08 \\
\hline Vetox -85 & 28 & 25 & 38 & 52 & 27 & 535 & 3.34 \\
\hline Furadan & 65 & 31 & 27 & 17 & 18 & 372 & 2.33 \\
\hline \multicolumn{8}{|l|}{$\begin{array}{l}\text { Grand mean }(x=2.57) \\
\text { (G.) Harvesting }\end{array}$} \\
\hline $\begin{array}{l}\text { Done in the morning/evening } \\
\text { (H.) Storage procedure }\end{array}$ & - & - & - & - & 160 & 800 & 5.00 \\
\hline Sorting out diseased and bruised produce & - & - & - & 71 & 89 & 729 & 4.56 \\
\hline $\begin{array}{l}\text { Use of well-ventilated containers such as smooth } \\
\text { basket }\end{array}$ & - & - & - & - & 160 & 800 & 5.00 \\
\hline $\begin{array}{l}\text { Storage in ambient temperature (Bunching - up } \\
\text { method) }\end{array}$ & - & - & - & - & 160 & 800 & 5.00 \\
\hline Grand mean $(x=4.89)$ & & & - & & & & \\
\hline
\end{tabular}

Source: Field survey, 2018 


\section{Field preparation}

On field preparation, the mean score for sunken bed was $(\bar{x}=2.96)$ while that of check basin was $(\bar{x}=3.47)$ with a grand mean for the land preparation as $(\bar{x}=3.19)$ out of the maximum of 5 -point scale. These findings imply that sunken bed method was till at the trial stage while check basin was at the evaluation level. This can be attributed to the fact that water pump and tube well which are meant for carrying out check basin field preparation had not been acquired by the majority of the respondents; hence, old methods of field preparation were still being used.

\section{Planting Distance}

Table 2 further reveals the planting distance of the vegetable production practices. The mean adoption score of the recommended planting distance for Telfaria $(50 \times 50 \mathrm{~cm})$ had a mean score of 2.78, Okra $(60 \times 60 \mathrm{~cm})$ had 2.7 , Amaranthus $(50 \times 30) 3.04$ and tomatoes $(50 \times 30 \mathrm{~cm})$ had a mean score of 3.38 , with a grand mean of $(\bar{x}=2.99)$. This implies that majority of the respondents were still at the evaluation level of adopting the improved distance of many of the vegetable production. The grand mean adoption score from the four vegetables improved practices studied was 2.99 out of the maximum of 5 points. This implies that majority of the women farmers were still at the trial level of adopting the improved planting distance of the improved vegetable.

\section{Water management}

Table 2 also shows that mean adoption score for the use of water pump was $(\bar{x}=3.16)$ while that of tube well was $(\bar{x}=3.69)$. The grand mean for the two technologies was $(\bar{x}=3.43)$. This implies that majority of the respondents were still at the evaluation level on the adoption scale with respect to the improved water management practices. The observed low level of adoption could be attributed to the initial high cost of procuring them by the farmers (Nwalieji and Ajayi, 2009).

\section{Fertilizer application}

The table also indicates that the mean adoption scores for the use of organic fertilizers (compost poultry droppings) and use of inorganic fertilizers (N.P.K) were 4.5 and 3.33 respectively. The grand mean adoption score was 3.45. This implies that use of organic and inorganic fertilizers was still at its evaluation level of adoption.

\section{Pesticide/herbicide}

The use of herbicide for planting vegetable crops revealed that round-up had a mean score of $\bar{x}=$ 2.54 while karate (insecticide) had a mean score of $\bar{x}=2.08$, VETOX had 3.34 and Furadam 2.33. The grand mean adoption score of pesticide/herbicide is 2.57 . This implies that pesticide/herbicide is still at the trial level on the scale. 


\section{Harvesting}

Harvesting of the vegetables crops either in the morning or in the evening had a mean score of $\bar{x}$ $=5.00$. It is the only practice that had full adoption.

\section{Storage procedure}

Table 2 also shows the mean adoption of storage practices. The result revealed that sorting out disease and bruised produce had a mean score of $\bar{x}=4.56$, use of well-ventilated containers such as smooth practice $(\bar{x}=5.00)$ and storage in ambient temperature (bumching up method) ( $\bar{x}$ $=5.00)$. The grand mean adoption score is 4.89 . This implies that storage procedure was still at the trial level.

On the whole, the adoption status of the respondents after introduction of the NFDP - Phase 1 low irrigation technology on vegetable production was poor. Full adoption was not recorded after twenty-three years of dissemination of the practices in the Zone.

\section{Determinants of Adoption of Improved Practices by the Farmers}

Table 3 shows the result of the Probit analysis on the factors influencing women farmers' decision on adoption of improved vegetable production practices. The pseudo $\mathrm{R}^{2}$ was 0.6493 , which implies that all the variables included the model were able to explain $64 \%$ of the probability of the women decision to adopt or not to adopt improved vegetable production practices. The result of the analysis revealed a good fit of the model as indicated by highly significant chi-square test statistics $\left(22.4932^{\star * *}\right)$ at $1 \%$ level of significance and the percentage of the variables correctly classified.

Table 3: Factors influencing adoption of Improved Vegetable Production in the study area using Probit regression

\begin{tabular}{llll}
\hline Variables & Coefficient & Standard error & $\mathbf{t}$ - value \\
\hline Constant & 6.298807 & 3.98062 & $2.55237^{\star *}$ \\
Age & 0.992518 & 0.05573 & -0.31358 \\
Farm size & 1.00188 & 0.80228 & 0.3569158 \\
Education & -0.1671805 & 0.71501 & 0.0870768 \\
On farm demonstration & 0.0870768 & 0.01304 & $2.900749^{* *}$ \\
& 0.0870768 & 0.21243 & -0.000083 \\
Family labour & 1.295902 & 0.00017 & 1.1475157 \\
Credit access & 1.892888 & 0.37057 & $4.704902^{* * *}$ \\
\hline Chi ${ }^{2}\left(X^{2}\right)$ & $22.4932^{* * *}$ & & \\
Pseudo R & 0.6493 & & \\
Log likelihood & 232.9932 & & \\
\hline
\end{tabular}

Source: Field survey, 2018. ${ }^{*} \mathrm{P} \leq 0.10,{ }^{* *} \mathrm{P} \leq 0.05,{ }^{* * *} \mathrm{P} \leq 0.01$ 
The result shows that age $\left(-0.3135258^{* * *}\right)$ had a negative significance, implying that as the farmers advance in age, they tend to adopt less practices as compared to the younger farmers. This is because as the farmers grow older, there is an increase in risk aversion and a decreased interest in long-term investment in the farm. This result confirms the apriori expectation for this study and agrees with study by (Udimal et al., 2017) which reported that older farmers are averse to technology adoption.

Farm size $\left(1.00188^{* * *}\right)$ was positive and significantly related to the adoption of improved vegetable production practices at $1 \%$ level. The implication is that improved vegetable production practices should target farmers with many numbers of plots since they have the potential of adopting the practices. Farmers with many plots are likely to adopt a new practice as they can afford to devote part of their land to try new practice fully, unlike those with few plots. The positive influence of farm size on adoption may be attributed to economics of scale effects or the ability to bear the risks associated with the adoption of new practices. This study confirms the study by Akudugu et.al; (2012) which revealed that farm size influences adoption of practices.

The coefficient of family labour $\left(1.147157^{* * *}\right)$ had a positive sign in relation to adoption of improved vegetable production practices. This implies that a farmer with family labour is more likely to adopt the practice than those without family labour. Vegetables requires timely planting, prompt weeding and harvesting and all these activities are labour intensive. As a result, farmers who were sure of labour were more likely to adopt the practice. The finding is in consistent with the study of Akudugu et al, (2012) which indicated that the cost of labour is a hindrance to technology adoption.

Further still, the result revealed that access to credit $\left(4.704902^{* *}\right)$ had a positive influence on adoption of improved vegetable production practices. This can be because of the risk associated with the adoption of the improved vegetable production practices. The practice comes as a package and needed to be adopted in full to achieve the desired result. A farmer who is profit oriented may not adopt the package if she were not sure of the ability to adopt every package associated with the practices. The result reveals that farmers who had access to credit were more likely to accept the practice relative to those without access to credit. Credit to farmers enables them to purchase the inputs that are required in the production process hence, its influence on farmers' adoption of improved vegetable production practice. The result confirms the finding of (Nwaru, 2005), which stated that access to credit promotes the adoption of risky practices through relaxation of the liquidity constraint as well as through the boosting of household risk bearing ability. 
On farm demonstration $\left(2.900749^{* * *}\right)$ was positive and significantly related to adoption of the improved vegetable production practices. The implication of the result is that an increase in the attendance to demonstration trials led to increase in the adoption of the practice. The result agrees with the apriori expectation that extension services and demonstration trials expose households to benefits inherent in new practices, thereby enhancing the uptake.

The compatibility of the practices $\left(-3.513968^{* *}\right)$ was significant but negatively related to the adoption of the practices at $5 \%$ level. The compatibility of the practice indicates the degree to which that practice is consistent with the existing social values, norms, experiences and needs of potential adopters. The implication is that if the package is not compatible with existing practices, it becomes difficult for adopting the practice. This attribute plays a significant key role in influencing the speed of adoption.

\section{Conclusion}

The study investigated factors influencing adoption of improved vegetable production practices in Aguta Agricultural Zone of Anambra State. The result of the study indicated a sequence of agricultural practice adoption approach. The farmers did not adopt the practices as a package but rather adopted a single component or a few suitable practices. The study further indicates that all the variables (age, farm size, education, on-farm demonstration, family labour, credit access and compatibility) used for the analysis were significantly related to adoption of the practice.

\section{Recommendations}

In order to improve the efficiency and use of this practice among the farmers in the study area, it is recommended that extension agents should re-introduce the practices using result-demonstration methods on controlled plots so as to encourage farmers to continue with the practices. Access to credit is also necessary to encourage more women to purchase all the input necessary for their activities. Formation of cooperatives should also be encouraged to address the constraints that the farmers currently face in term of small farm size. 


\section{REFERENCES}

Adebiyi, S. and Okunlola J. (2013). Factors affecting adoption of Cocoa farm rehabilitation techniques in Oyo State of Nigeria. World Journal of Agricultural Sciences, 9(3), 258 265.

Agu, V. C. (2002). Comparative study of the extension systems of the agricultural and community development organizations in Sokoto, Nigeria. Unpublished Ph.D Thesis, Department of Agricultural Extension, University of Nigeria, Nsukka, pp. 21 - 24.

Agwu, A. and Anyaeche, C. (2007). Adoption of improved cassava varieties in six rural communities in Anambra State, Nigeria. Asian Journal of Biotechnology, 6(2), 90-98.

Akudugu, M. A., Guo, E. and Dadzie, S. K. (2012) Adoption of modern agricultural technologies by farm Households in Ghana; what factors influences their decision? Journal of Biology, Agricultural and Healthcare, 2(3), 1-13

Etuk, E. A., Udoe, P. O. and Okon, I. I. (2018). Determinants of Livelihood Diversification among Farm Households in Akamkpa Local Government Area, Cross River State, Nigeria. Agrosearch, 18(2), $88-110$.

Ironkwe, A. G., Ezebuiro, N. C. and Ewuziem, J. E. (2016). Adoption of root and tuber technologies. Disseminated by National Root Crop Research Institute in Anambra State. Journal of Agricultural Extension, 20(1), 39-52

Kariyasa, K. and Dewi, A. (2011). Analysis of factors affecting adoption of integrated crop management farmer field school (ICM Ffs) in swampy area. International Journal of Food and Agricultural Economics, 1(2), $29-38$.

Matata, P. Z., Ajay, O. C., Oduol, P. A. and Agumaya, A. (2010). Socio-economic factors influencing adoption of improved fallow practices among small holds farmers in western Tanzania. African Journal of Agricultural Research, 5(8), $818-823$.

Mwangi, M. and Kariuki, S. (2015). Factors determining adoption of new agricultural technology by small holder farmers in developing countries. Journal of Economics and Sustainable Development, 6(5), 208-216

Nwadukwe, P. O. (2000). Fadama Programme in Anambra State: concepts, principles and practices. Paper presented at the Fadama Sensitization workshop organized by the ASADEP, Awka, Nigeria, 14 - November, pp. $1-6$.

Nwalieji, A. H., \& Ajayi, A. R. (2009). Farmers' adoption of improved vegetable production practices under the National Fadama Phase One Development Project in Anambra State of Nigeria. African Journal of Biotechnology, 8(18), 4395-4406 
Nwaobiala C. U, Alozie E. N and Anusiem C. N (2019), Gender Differentials in Farmers' Involvement of Cassava Production Activities in Abia State, Nigeria. Agrosearch, 19(1), $72-86$.

Nwaru, J. C. (2005). Determinant of farm and off-farm incomes and savings of food crop farmers in Imo State. Implications for poverty alleviation. The Nigerian Agricultural Journal, 36, 26-42.

Oyedoyin, B. O., llori, M. O., Oyebisi, T. O., Oluwale, B. A., and Jegede, O. O. (2013). Technology transfer process in Nigeria: from R\&D outputs to entrepreneurship. International Journal of Technology Transfer and Commercialisation 12(124), 216-230

Udimal, T. B., Jincai, Z., Mensali, O. W. and Caesar, A. E. (2017). Factors influencing the agricultural technology adoption. The case of improved rice varieties (Nerica) in the Northern Region. Ghana Journal of Economics and sustainable development, 8(8), 137-148 